\title{
Meat Quality of Japanese Quail (Coutonix Coutonix Japanica) Fed Graded Levels of Fermented Mango Kernel Meal
}

\author{
Samson, Kyakma S., Idu Gibson and Wilson Makir
}

Department of Animal Production, Federal University of Agriculture Makurdi, pmb 2373, Makurdi, Benue State of Nigeria

\begin{abstract}
This study is aimed at evaluating the effect of replacing maize with Fermented Mango Kernel Seed Meal(FMKSM) on meat quality of Japanese Quails . A total of two hundred and twenty five (225) one week old unsexed Japanese quails purchased from National Research Institute Vom, Plateau State, Nigeria were used in a six weeks study. The quails were equally allotted in to five treatment group of 45 birds per treatments. The control diet which contains 0\% FMSKM and four other experimental diet in which maize was replaced with FMSKM at 10\%, $15 \%, 20 \%$ and $25 \%$ levels of inclusion thus; 5 treatments respectively. At the end of the experiments, cooking loss, drip loss, Colour and $\mathrm{pH}$ were analyzed. From the results, cooking loss, drip loss, Colour and $\mathrm{pH}$ showed no significant differences ( $p>0.05)$ across treatments. Only water holding capacity at $25 \%$ inclusion of FMSKM showed a significant difference $(p<0.05)$. The result showed that the ater holding capacity remained constant through treatment 1-4 (100\%),it then decreased at treatment 5. It was concluded that $20 \%$ inclusion of FMSKM is recommended in the feeding of meat type Japanese quail without having any effect on these meat quality parameters.
\end{abstract}

Keywords- Japanese Quail, Coutonix Coutonix Japanica, Mango Kernel Meal.

\section{INTRODUCTION}

Quail rearing for meat and egg production is becoming an economically viable activity in some places of the world and has increasingly developed. From the technical and economic viewpoints, quail rearing is attractive due to their rapid growth and early onset of lay, high reproduction rates, and low feed intake (Murakami \& Ariki, 1998; Albino \& Barreto, 2003).

Physical properties and eating quality of meat are affected by cooking temperature and time. During cooking, the distinctive meat proteins are denatured and this reasons structural changes in the meat textural profile. These resulted in destruction of cell membranes, shrinkage of meat fibres, the aggregation and gel formation of myofibrillar and sarcoplasmic proteins, and shrinkage and solubilization of the connective tissue Tornberg E. (2005). Heat treatment can result to undesirable meat quality changes, such as nutritive value loss because of lipid oxidation and changes in a few segments of the protein fraction (Sa-adchom et al., 2011).

The most important poultry meat quality attributes are appearance and texture because they most influence consumers' initial selection and ultimate satisfaction with products. Moreover, one of the major contributing components of appearance is color (Fletcher et al., 2000). The author, taking into account the results of much research, concluded that the major factors affecting poultry meat color were heme pigment content of meat and also preslaughter, postslaughter, and slaughter factors. The best way to determine the texture of cooked meat is through the sensory analysis of experienced panelists, which is an expensive and demanding method. Warner-Bratzler (WB) shear test for toughness of cooked meat is the most widely used and primary method (Cavitt et al., 2005; Lee et al., 2008).

Meat quality is significantly affected by preslaughter factors. Atmospheric conditions in the pre-slaughter period, and especially those causing an additional stress for animals can be important. Seasonal changes in temperature can affect the level of glycogen in muscles after slaughter and the ultimate $\mathrm{pH}$, and consequently the quality of meat. An increase in glycolysis results from excessive excitement, starving and stress caused by ambient temperature, which in turn leads to high post-mortem $\mathrm{pH}$ values and consequently meat colour is influenced (Kreikemeier et al., 1998; Abril et al., 2001; Honkavaara et al., 2003). The problem of seasonal changes in meat quality caused by temperature stress was studied by many authors (Fabiansson et al., 
1984; Jones and Tong, 1989; Mitlöhner et al., 2002; Kadim et al., 2004).

Quail production for meat is becoming a viable activity in some places in the world therefore this study is done to ascertain the quality of quail meat fed graded level of fermented mango kernel meal.

\section{Objectives of study}

To determine the effect of graded levels of fermented mango seed kernel on the meat quality of Japanese quail.

\section{Justification}

This study is done to improve the meat quality of Japanese quail using grade levels of fermented mango seed kernel since the protein content of the fermented mango seed kernel is more than that in maize.

\section{Objectives}

The study is done to reduce the production cost in poultry farming and yet achieve a good meat quality since the energy and protein level of fermented mango kernel seed can be compared to that maize.

\section{MATERIALS AND METHOD}

\section{Physical Parameters Measured}

Physical analysis of the meat quality was done using 3 birds randomly picked from each treatment (1-5) to measure and study some qualities of their meat using the following parameters;

- Colour

- $\mathrm{Ph}$

- Water holding capacity

- Driploss

- $\quad$ Cooking loss

PROCEDURES

\section{Colour}

A chunk of lean meat was cut from the slaughtered birds of the various treatments with knife and brought close to the CIE LAB colour chat. The reading wastakenbase on the similarity of the colour of the meat to that on the CIELAB colour chat following the model of the commission Iternationionale d'Eclairge $\mathrm{L}^{*} \mathrm{a} * \mathrm{~b} *$ system was used, where $\mathrm{L}^{*}$ is the lightness of the meat, $\mathrm{a}^{*}$ the redness and $\mathrm{b}^{*}$ the yellowness (Swatland, 1985; Monnin, 1998). This was done at slaughter (0 hour), 4 hours, and 24 hours .

\section{2. pH measurement}

After slaughter, breast fillets were directly measured using $\mathrm{pH}$ meter with 0.01 precision (Sentro, model 1001).

\section{Water holding capacity}

Water holding capacity was evaluated using a method adopted from Hamm (1960), based on meat water loss when pressure is applied on the muscle. Meat cubes weighing $2 \mathrm{~g}$ were cut and laid between two filter papers circles. The weight of $10 \mathrm{~kg}$ was placed on it for 5minutes and afterwards, it was re-weighed. Water holding capacity was calculated as initial weight minus final weight and expressed as percentage. Statistically

weight)/1 x 100

(Initial weight - final

\section{Drip Loss}

To determine the drip loss, breast fillet samples of $10 \mathrm{~g}$ was remove from the carcass of the various treatments and stored in plastic trays covered with water proof foil paper and refrigerated for 24hours. After this period, exudates were discarded and the samples were weighed following the procedures of Northcut et al., (1994) and Dirik et al., (1996). Drip loss was calculated as initial weight minus final weight and expressed as percentage. Statistically;

(Initial weight - final weight)/1

X 100

\section{Cooking loss}

Samples were weighed and put in plastic bags and cooked in boiling water of about $82-85^{\circ} \mathrm{C}$ for 10 minutes and allowed to cool on absorbent paper at room temperature. Samples were re-weighed following the procedures of Honikel, (1989). Cooking loss was calculated as; Initial weight - final weight.

\section{RESULTS AND DISCUSSION}

Table.1: Colour Measurement of Japanese Quail Meat fed Graded Levels of Fermented Mango Seed Kernel meal

\begin{tabular}{llll}
\hline TREATMENTS & $\begin{array}{l}\text { ( Hour } \\
\text { (at slaughter) }\end{array}$ & 4 Hours & 24 Hours \\
\hline T1 & $+\mathrm{b}^{*}$ & $+\mathrm{b}^{*}$ & $+\mathrm{b}^{*}$ \\
$\mathrm{~T} 2$ & $+\mathrm{a}^{*}$ & $+\mathrm{a}^{*}$ & $+\mathrm{a}^{*}$ \\
$\mathrm{~T} 3$ & $+\mathrm{b}^{*}$ & $+\mathrm{b}^{*}$ & $+\mathrm{b}^{*}$ \\
$\mathrm{~T} 4$ & $+\mathrm{b}^{*}$ & $+\mathrm{b}^{*}$ & $+\mathrm{b}^{*}$ \\
$\mathrm{~T} 5$ & $+\mathrm{b}$ & $+\mathrm{b}^{*}$ & $+\mathrm{b}^{*}$ \\
\hline
\end{tabular}




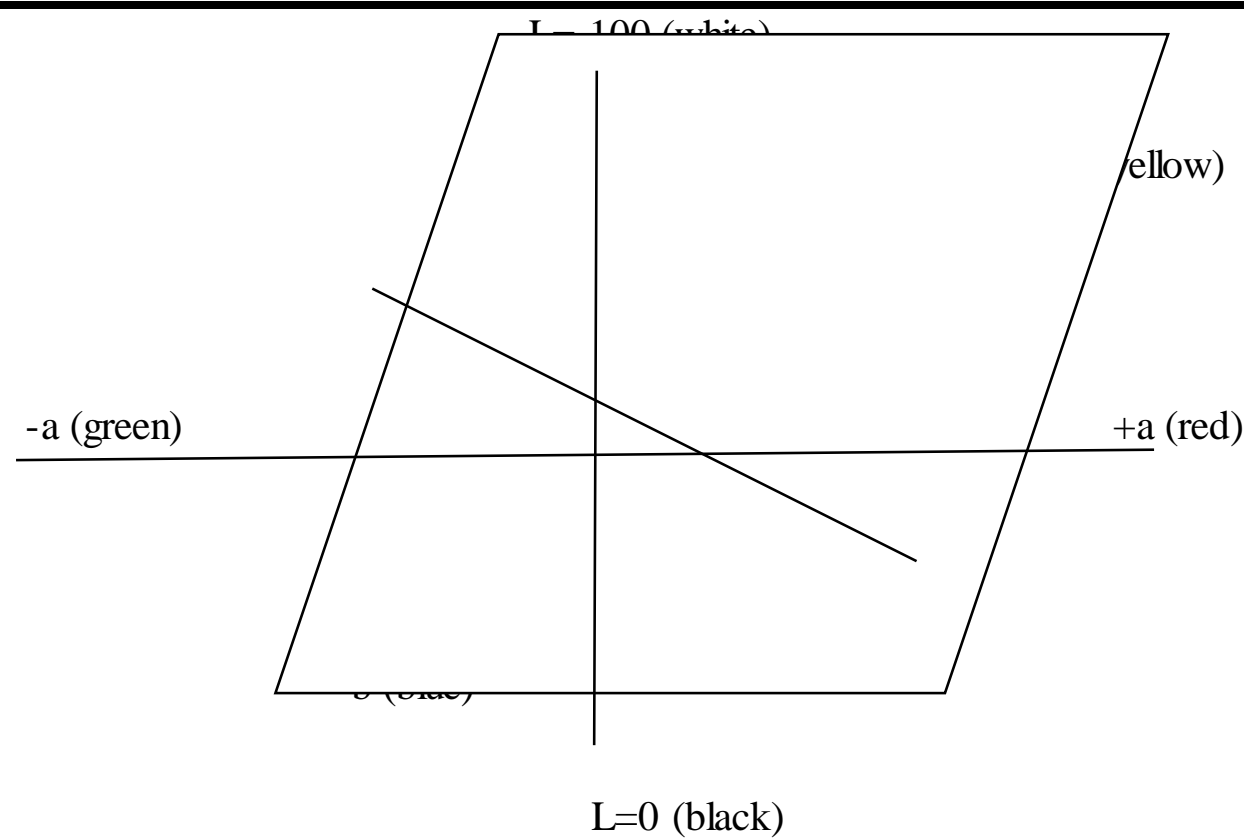

Diagram 1: Colour scale for determining meat colour

The colour of muscles was determined on post slaughter 0 , 4,24 , on each muscle. The determination was done on the longitudinal out surface of each muscle. The CIELAB colour system was used considering $1^{*}, a^{*}$, and $b^{*}$ calorimetric coordinates as follows:

1. $L^{*}$ a value 100 corresponded to absolute white value - Absolute black

2. $\mathbf{a}^{*} \mathbf{a}^{+}$corresponded to red spectrum. a corresponded to green spectrum.
3. $b^{*}-b^{+}$corresponded o yellow spectrum. b-Corresponded to blue spectrum.

Table 1 shows the result of evaluated meat parameter including lightness $\left(\mathrm{L}^{*}\right)$, redness $\left(\mathrm{a}^{*}\right)$ and yellowness $\left(\mathrm{b}^{*}\right)$. For treatment 1, 3, 4 and 5, the colour $\left(+b^{*}\right)$ was constant through 0 hour, 4 hours and 24 hours. Whereas, treatment 2 shows a different shade of colour $\left(+\mathrm{a}^{*}\right)$ from the other treatments through the time of slaughter ( 0 hour), 4 hours and 24 hours.

Table.2: pH measurement of Japanese quail Meat fed graded levels of Mango Seed Kernel

\begin{tabular}{llllllr}
\hline $\begin{array}{l}\text { Parameters } \\
\text { (HOUR) }\end{array}$ & Treatment 1 & Treatment 2 & Treatment 3 & Treatment 4 & Treatment 5 & SEM \\
\hline 24 hour (At Slaughter) & 3.10 & 3.07 & 2.67 & 2.87 & 0.10 & 2.65 \\
0 Hours & 4.87 & 4.93 & 4.17 & 4.17 & 4.67 & 0.22 \\
4 Hours & 3.50 & 4.00 & 4.37 & 4.77 & 4.00 & 0.33 \\
\hline
\end{tabular}

Table 2 shows the $\mathrm{pH}$ measurement for the various treatments from the time of slaughter, 4 hours and 24 hours. $\mathrm{pH}$ at 0 hour ranges from 2.65 to 3.10 with the highest in treatment 5. At 4 hours of slaughter the $\mathrm{pH}$ ranges from $4.67-4.87$ while those in 24 hours ranges from 3.50 to 4.77 with the highest in treatment 4.

Table.3: Effect offeeding graded levels offermented mango kernel seed on water holding capacity (WHC) and cooking loss of Japanese quail meat.

\begin{tabular}{lllllll}
\hline PARAMETERS & Trt 1 & Trt 2 & Trt 3 & Trt 4 & Trt 5 & SEM \\
\hline WHC & 100 & 100 & 100 & 100 & 66.67 & 6.67 \\
Cooking Loss & 6.00 & 6.00 & 4.67 & 7.00 & 7.00 & 0.78 \\
Drip Loss & 33.33 & 66.67 & 100.00 & 66.67 & 100.00 & 18.17 \\
\hline
\end{tabular}

Trt = treatment, $\mathrm{WHC}=$ water holding capacity 


\section{DISCUSSION}

From this study, the meat colour of all the treatment (1-5) remained unchanged even during the process of transformation of muscle into meat. At slaughter, treatment $1,3,4$ and 5 showed a yellowish colour $\left(+b^{*}\right)$ this might be as a result of the environmental temperature when the study was carried out (at midday). It is known that detoriation sets in faster at higher temperatures than at lower temperatures which increases the $\mathrm{pH}$ therefore altering the colour from reddish $\left(+a^{*}\right)$ to yellowish $\left(+b^{*}\right)$. This result is within the range observed by Owens et al.(2000), Woelfelet al.(2002), Woelfel and Sams (2001), Barbut (1998), and Vimini (1996), whom observed 2 to $50 \%$ yellowish colour in chicken breast fillets, depending on environmental conditions. Treatment 2 shows redness, this may be due to the 5\% inclusion of the Fermented Mango Seed Kernel in the fed of the birds. However, the incidence observed in this present experiment is lower than that found by Lara (2003), who evaluate PSE percentage in the meat of broilers submitted to heat stress before slaughter and obtained incidences of $35.30 \%$ in non-stressed and $37.08 \%$ in heatstressed birds.Some authors reported a significant effect of environmental temperature on meat colour (Owens et al., 2000; Guarnieriet al., 2002).

A pH of 4.93 at slaughter was observed and falls between the range of 5-5.9 recorded by several researchers Oguzet al.(2009); Gevrekciet al.(2009). Some authors (Genchev et al., (2008)(2010) reported the value of 6.17 and 6.00 at slaughter which is higher than the 4.87 reported in this study. The difference might be due to different sanitary measures during slaughter which might increase the microbial load leading to a higher $\mathrm{pH}$. The lower $\mathrm{pH}$ might indicate a higher microbial load in the meat samples after 4 hours of slaughter. It is an established fact that at room temperature, microbial load multiply as the keeping time is been lengthened which leads to a higher $\mathrm{pH}$. So also karakaya et al. (2005) reported the $\mathrm{pH}$ of 5.59 at slaughter which is not far from the value obtained in this study. In a study carried out by Singh and Verma 1995, they recorded the $\mathrm{pH}$ of 5.8 to 5.9 at slaughter and a rapid decrease 2 hours after slaughter due to high microbial load at room temperature.

The water holding capacity as presented in Table 3 , showed no significant difference $(\mathrm{P}>0.05)$ across the treatments. This stands to reas on that quail meat has high water holding capacity regardless of it been fed the normal ration in treatment 1 which is the control nor been fed the experimental diet. From this study, it was observed that the water holding capacity remain constant (100\%) in treatment
$1-4$ and decreased in treatment 5 (25\% inclusion of experiment diet). This implies that the inclusion of fermented mango kernel up to $25 \%$ may affect the water holding capacity of the meat. Bower et al., (2014) in his study gave a range of $74-92 \%$ which falls between the range of $66.67-100 \%$ obtained in this study. A lower value to that obtained in this study was recorded by Woelfel et al., (2002) who found $47 \%$ of pale fillets out of a total of 3,554 fillets evaluated in commercial processing plant that could be potentially classified as PSE, and presented low water holding capacity. In line with this study, Garcia et al., (2010) recorded and average value of 64.79 in the water holding capacity of normal fillets of chicken meat. This study is also consistent with the studyof Weeranantanaphan et al., (2009) who stated that water holding capacity cannot be predicted in fresh meat to the same degree of accuracy as the chemical composition of the meat.

The cooking loss was observed to have increase at treatment 4 (20\% inclusion of test ingredient) and treatment 5 (25\% inclusion of test ingredient). This study achieve a similar cooking loss value $(14.6 \%)$ in broiler chicken reported by Le Bihn-Duval et al., (2008). Similarly, Garcial et al., (2010) recorded 19.45 cooking loss value in chicken meat in a commercial processing plant. Dogan et al., (2013), reported a cooking loss of $24 \%$ which is higher than that obtained from this study, the disparity can be attributed to difference in time, temperature, ultimate $\mathrm{pH}$ and the type of muscle cooked.

Drip loss in this experiment shows no significant difference $(\mathrm{P}>0.05)$ across the treatment, it increases across the treatments having its least value in treatment 1 which is the control. Treatment 3 and 5 having 15\% and 25\% inclusion of the experimental ingredient shows a higher drip loss of $100 \%$, this may imply that $15 \%$ and $25 \%$ inclusion of fermented mango kernel seed is not advisable. This is consistent with the study of Kauffman et al., (1992) who reported that an unacceptably high moisture loss from fresh product as purge or drip has been estimated to occur in as much as $50 \%$ of the pork produced. In contrary to this study, Garcia et al., (2010) observed a little drip loss of 1.37 in chicken meat in a commercial processing plant.

\section{CONCLUSION}

The result obtained in this study shows that up to $20 \%$ fermented mango seed kernel can be included in the diet of quail birds without deleterious effect on their cooking loss, drip loss, colour and $\mathrm{pH}$ which are important factors in measuring meat quality. 


\section{REFERENCES}

[1] Albino L.F.T, Barreto S.L.T. (2003). Criação de codornas para produção de ovos e carne. Viçosa: Aprenda Fácil;. 268p.

[2] Barbut S. (1998). Estimating the magnitude of the PSE problem in poultry. Journal Muscle Foods 1998; 9:3549

[3] Cavitt L. C. Meullenet J. F. Gandhapuneni R. K. Youm G. W. Owens C. M. (2005). Rigor development and meat quality of large and small broilers and the use of Allo-Kramer shear, needle puncture, and Razor Blade shear to measure texture. Poultry Science 84:113-118.

[4] Dogan, N. Tulin A., Emre K., Ali A., Mehmet Z.F., Mustafa K.U., (2013). Japans quail meat quality: characteristics, Heritabilities, and Genetic correlations with some slaughter traits. Poultry Science, volume 92. Pp 1735-1744

[5] Fabiansson S., Erichsen I., Reuterswrd A.L., Malmfors G. (1984). The incidence of dark cutting beef in Sweden. Meat Science, 10, 21-33.

[6] Fletcher D. L. Qia M. Smith D. P. (2000). The relationship of raw broiler breast meat color and $\mathrm{pH}$ to cooked meat color and pH. Poultry Science 79:784788 .

[7] Garcia, R.G., Freitas L.W de, Schwingel A.W, Farias R.M., Caldara F.R., Gabriel A.M.A., Graciano J.D., Komiyama C.M., Almeida Paz I.C.L. (2010). Incidence and Physical Properties of PSE Chicken Meat In A Commercial Processing Plant. Brazilian Journal of Poultry. ISSN 1516-635X

[8] Genchev A. Mihaylov R. Ribarski S. Pavlov A. Kabakchiev M. (2008). Slaughter analysis protocol in experiments using Japanese quails ( Coturnix japonica). Trakia Journal of Science 6:66-71.

[9] Gevrekci Y. Oguz I. Aksit M. Onenc A. Ozdemir D. Altan O. (2009). Heritability and variance component estimates of meat quality in Japanese quail ( Coturnix coturnix japonica). Turkey Journal of Veternary and Animal Science 33:89-94.

[10] Guarnieri P.D, Olivio R, Soares A.L, Ida E.L, Lara J.A.F, Shimokomaki M. (2002). Bem estar animal e qualidade da carne: uma exigencial dos consumidores. Revista Nacional da carne 26:36-44

[11] Kadim I.T., Mahgoub O., Al-Ajmi D.S., AlMaqbaly R.S., Al-Mugheiry S.M., Bartolome D.Y. (2004). The influence of season on quality characteristics of hot-boned beef $m$. longissimus thoracis. Meat Science, 66, 831-836.
[12] Karakaya M. Saricoban C. Yilmaz M. T. (2005). The effect of various types of poultry pre- and post-rigor meats on emulsification capacity, water-holding capacity and cooking loss. Europe Food Research Technology 220:283-286.

[13] Kreikemeier K.K., Unruh J.A., Eck T.P. (1998). Factors affecting the occurrence of dark-cutting beef and selected carcass traits in finished beef cattle. Journal of Animal Science, 76, 388-395.

[14] Le Bihan-Duval E. Debut M. Berri C. M. Sellier N. Santé-Lhoutellier V. Jégo Y. Beaumont C. (2008). Chicken meat quality: Genetic variability and relationship with growth and muscle characteristics. BMC Genet. 9:53.

[15] Lee, J.H., Kouakou, B. \& Kannan, G., (2008). Chemical composition and quality characteristics of chevon from goats fed three different post-weaning diets. Small Ruminant Research.75, 177-184.

[16] Murakami AE, Ariki J. (1998). Produção de codornas japonesas. Jaboticabal: FUNEP, 79p.

[17] Oguz I. Aksit M. Onenc A. Gevrekci Y. Ozdemir D. Altan O. (2004). Genetic variability of meat quality characteristics in Japanese quail ( Coturnixcoturnix japonica). Arch. Geflügelk. 68:176181.

[18] Owens C.M, Mckee S.R, Matthews N.S, Sams A.R. (2000). The development of pale, exudative meat in two genetic lines of turkeys subjected to heat stress and its prediction by halothane screening. Poultry Science 79:430-435

[19] Vimini R.J, (1996). Overview of typical poultry meat in relation to PSE pork from a global level. Annual meeting of the IFT; New Orleans, LA.

[20] Woelf R.L, Sams A.R, (2001). Marination peformence of pale broiler breast meat. Poultry Science; 80:15191522.

[21] Woelfel R.L, Owens C.M, Hirschler E.M, MartinezDawson R, Sams A.R (2002). The characterization and incidence of pale, soft and exudative broiler meat in a commercial processing plant. Poultry Science 81;579584. 